\title{
WYKORZYSTANIE ROZWIĄZAŃ BIG DATA W ZARZĄDZANIU PRZEDSIĘBIORSTWEM
}

$\mathrm{Z}$ a r y s t r e ś c i: W opracowaniu zaprezentowano koncepcję big data w zarządzaniu przedsiębiorstwem. Pierwsza część artykułu dotyczy istoty i założeń w podejściu big data. W drugiej części przedstawiono wyniki badań empirycznych. Za pomocą ujęcia komparatywnego wskazano różnice w wykorzystaniu rozwiązań big data na tle różnych cech przedsiębiorstw. Przeprowadzona analiza przyczynia się do określenia specyfiki praktycznej użyteczności koncepcji big data w polskich przedsiębiorstwach.

S 1 o w a k 1 u c z o w e: koncepcja big data, przedsiębiorstwo, zarządzanie, systemy wspomagania organizacji.

K 1 a s y fik a c j a E L: L21

\section{WSTĘP}

Zjawisko Big Data jest nazywane rewolucją w zakresie analityki biznesowej, która zmieni oblicze biznesu, ale i również sposób myślenia, życia i pracy wielu ludzi na całym świecie [Mayer-Schönberger, Cukier, 2014]. Zainteresowanie nim coraz szybciej rośnie, szczególnie wśród zarządzających współczesnymi organizacjami [Wielki 2014, s. 83]. Koncepcja big data $\mathrm{w}$ zarządzaniu przedsiębiorstwem dotyczy nowoczesnego podejścia do analizy danych, które obejmuje możliwości ich gromadzenia, przetwarzania i wizualizacji dla szerokich potrzeb w różnych dziedzinach funkcjonowania przedsiębiorstwa [Gandomi, Haider, 2015]. W ciągu ostatnich 5 lat nastąpił wyraźny wzrost publikacji dotyczących big data w różnych dyscyplinach

\footnotetext{
* Adres do korespondencji: Adam Weinert, Uniwersytet Ekonomiczny w Poznaniu, Wydział Zarządzania, Katedra Zarządzania Strategicznego, al. Niepodległości 10, 61-875 Poznań, e-mail: adam.weinert@ue.poznan.pl.
} 
naukowych, również w naukach o zarządzaniu [Frizzo-Barker i inni, 2016].

Artykuł podzielono na dwie części. W pierwszej skoncentrowano się na przedstawieniu istoty i założeń koncepcji big data w zarządzaniu. Druga przestawia wyniki badania z perspektywy menedżerów w polskich przedsiębiorstwach. Problemem badawczym jest praktyczna użyteczność koncepcji big data w kontekście zarządzania przedsiębiorstwem. Zastosowano analizę porównawczą, która pozwoli wskazać różnice w zakresie wykorzystania rozwiązań big data na tle różnych cech charakteryzujących działanie przedsiębiorstw.

Jak podkreśla wielu naukowców zagadnienia związane z podejściem big data stanowi interesującą problematyką badawczą, która jednocześnie jest sporym wyzwaniem dla praktyków z obszaru biznesu, ale także gospodarki i społeczeństwa [Lau i inni, 2015].

W literaturze przedmiotu widać gwałtowny wzrost zainteresowania pojęciem big data, w szczególności od 2012 roku, na co wskazują autorzy opracowań bazujących na systematycznym przeglądzie literatury (przeprowadzonym dzięki artykułom zawartym w bazach publikacji, które zawierają liczne periodyki naukowe) [m.in. Wamba i inni, 2015; Frizzo-Barker i inni, 2016]. Z całą pewnością tematyka big data zyskuje na dużym rozgłosie, co jest związane pośrednio z sytuacją, w której dostrzega się dynamiczne zmiany w otoczeniu biznesowym. Przedsiębiorstwa szukają nowych możliwości zdobycia przewagi konkurencyjnej, a jednym z możliwych kierunków jest wdrażanie rozwiązań big data, zaliczających się do systemów wspomagania organizacją (SWO). Ich celem jest usprawnianie systemu informacyjnego przedsiębiorstwa w czasie rzeczywistym.

\section{KONCEPCJA BIG DATA - ISTOTA I ZAŁOŻENIA}

Termin big data nie ma jednoznacznie przedstawionej definicji w literaturze przedmiotu. Jednak bardzo często w opisie tego zagadnienia wykorzystuje się model 3V: volume, velocity i veracity. Model ten znajduje również rozszerzenie o kolejne dwie składowe - value i veracity [White 2012]. Wskazane elementy stanowią trzon ogólnej koncepcji, która obowiązuje w kontekście podejścia do analityki biznesowej w przedsiębiorstwie. W tabeli 1 przedstawiono wybrane definicje pojęcia big data, których analiza pozwala zrozumieć zakres pojmowania $\mathrm{i}$ interpretowania tego zagadnienia. $\mathrm{Z}$ kolei na rysunku 1 zaprezentowano schemat modelu $5 \mathrm{~V}$. 
Tabela 1. Wybrane definicje pojęcia big data w literaturze przedmiotu

\begin{tabular}{|l|l|}
\hline Autorzy & Definicje \\
\hline Cosic i inni (2012) & $\begin{array}{l}\text { Zdolność do wykorzystywania zasobów i wykonywania zadań zwiazanych z ana- } \\
\text { lizą biznesową. }\end{array}$ \\
\hline Hurwitz i inni (2013) & Zdolność do zarządzania ogromną ilością danych rozproszonych. \\
\hline LaLalle i inni (2011) & $\begin{array}{l}\text { Podejście do redukcji kosztów i optymalizacji wydajności pracy. Nastawienie na } \\
\text { osiaganie korzyści poprzez analizę danych. }\end{array}$ \\
\hline Simon (2013) & $\begin{array}{l}\text { Zdolność do zbierania ogromnej liczby, różnorodność danych od klientów po to, } \\
\text { aby uzyskać informacje biznesowe w celu optymalizacji obsługi klienta. }\end{array}$ \\
\hline
\end{tabular}

Źródło: Opracowanie własne na podstawie [Wang i inni, 2016]

Dostrzega się, że model big data znajduje szerokie zastosowanie również wśród praktyków. Coraz częściej widać, że big data nie odnosi się już jedynie do zakresu danych, które są wykorzystywane do szerokich analiz, ale oznacza kompleksowe podejście do sposobu prowadzenia analityki biznesowej [Krauze, 2014].

Rysunek 1. Model 5V - big data

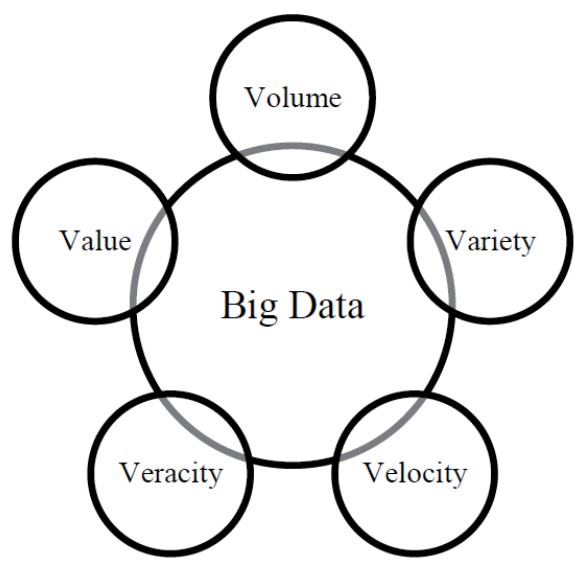

Źródło: [Elragal, 2014, s. 244]

Z punktu widzenia przedsiębiorstwa, koncepcja ta obejmuje zatem ogólny zbiór zagadnień dotyczący działań od przechowywania aż po wizualizację danych, które powinny przyczyniać się do podejmowania lepszych decyzji [Weinhofen, Mathisen, 2015]. Zaznaczyć należy, że do analiz big data mogą być wykorzystywane różne zbiory danych, bardzo często nieustrukturyzowane i o różno- 
rodnym formacie. Pochodzą one z rozmaitych źródeł informacji od aplikacji mobilnych, sieci społecznościowych aż po strumień kliknięć na stronach internetowych [Mach-Król 2015, s. 41]. Wielki [2014, s. 85] wskazuje, że big data charakteryzuje się przede wszystkim:

- rodzajem danych - dane nieustrukturyzowane,

- wielkością danych - 100 terabajtów do petabajtów,

- $\quad$ sposobem dopływu danych - stały wpływ danych do organizacji (w czasie rzeczywistym),

- podstawowa metoda analityczna - uczenie maszynowe,

- podstawowy cel wykorzystania - tworzenie nowych produktów.

Rozwiązania big data znajdują zastosowanie w wielu dziedzinach funkcjonowania przedsiębiorstw i instytucji publicznych. Do głównych z nich zalicza się m.in. bankowość, ubezpieczenia, finanse, telekomunikację, marketing i sprzedaż, turystykę, edukację, opiekę zdrowotną, hotelarstwo, logistykę i wiele innych [m.in. Özköse i inni, 2015, s. 1044]. Część autorów opracowań z zakresu użyteczności big data w zarządzaniu wskazuje, że katalog możliwości dla tego rodzaju analiz wydaję się być niewyczerpywalny.

Rysunek 2. Zastosowanie rozwiązań big data w różnych branżach

- Ogólnie biznes
- Finanse i zarządzanie
- Prawo
- Technologie informatyczne
- Opieka zdrowotna
- Edukacja
- Inne

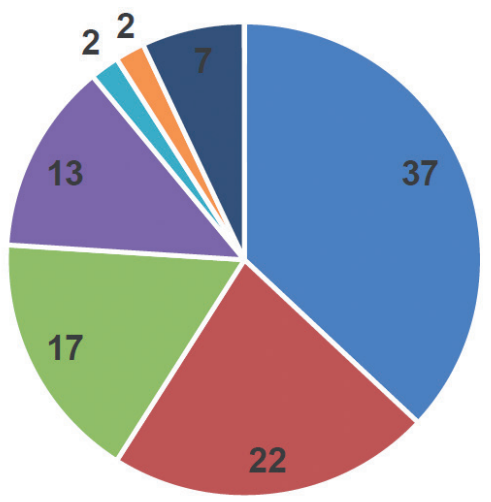

Źródło: [Frizzo-Barker i inni, 2016].

Niezależnie od dziedziny wykorzystywania big data w przedsiębiorstwie, podmioty te posiadają ogromne ilości nieuporządkowanych danych, które wymagają odpowiedniej architektury zasobów. Potrzebne najczęściej jest dedykowane oprogramowanie informatyczne wymagające nowoczesnego sprzętu, ale i odpowiednie umiejętności zarządzania nimi. Takie posiadają osoby zajmujące 
się profesjonalnie rozwiązaniami big data (ang. data scientists). Zakres dostępnych narzędzi na rynku dla analiz big data jest już bardzo szeroki [Frizzo-Barker i inni, 2016, s. 409]

Reasumując big data wykorzystuje się w wielu obszarach zarządzania przedsiębiorstwem. Jest to kompleksowe podejście, które obejmuje szeroki zakres zarządzania wielkimi wolumenami różnorodnych danych w czasie rzeczywistym. Jak podkreśla Płoszajski [2013, s. 6] big data stanowi nowe źródło przewag i wzrostu przedsiębiorstw, tworząc w rezultacie ,potężny i ekscytujący sektor”. Jak wiadomo innowacyjne technologie zmieniają sposób działania firm. Do jednych z nich należą właśnie rozwiązania big data, otwierając nowe perspektywy rozwoju współczesnego biznesu.

W drugiej części publikacji zostaną zaprezentowane wyniki badań empirycznych dotyczących praktycznego wykorzystania analiz big data w przedsiębiorstwach. Zastosowano ujęcie komparatywne, które pozwoliło wskazać przedsiębiorstwa stosujące analizę big data na tle różnych cech tych przedsiębiorstw. Analiza przyczynia się do określenia specyfiki praktycznej użyteczności koncepcji big data w polskich przedsiębiorstwach.

\section{WYKORZYSTANIE ROZWIĄZAŃ BIG DATA W OPINII MENEDŻERÓW}

Przestawione w drugiej części artykułu wyniki badań pochodzą z części projektu badawczego realizowanego $\mathrm{w}$ ramach badań statutowych Katedry Zarządzania Strategicznego Uniwersytetu Ekonomicznego w Poznaniu. Na potrzebę artykułu wykorzystano wybrany materiał, w którym skoncentrowano się na wykorzystaniu rozwiązań big data w zarządzaniu przedsiębiorstwem. W założeniach badania przyjęto, że podmiotem są członkowie najwyższego szczebla kierownictwa średnich i dużych przedsiębiorstw. Próba badawcza wyniosła 269 podmiotów, które zatrudniają powyżej 49 osób. Należy zaznaczyć, że udziały badanych jednostek w ramach poszczególnych sektorów były proporcjonalne do udziałów przedsiębiorstw w całej populacji (w zakresie każdej warstwy zastosowano losowanie proste bez zwracania). Jako instrument badawczy posłużył kwestionariusz ankiety. ${ }^{1}$

Przeprowadzona analiza danych empirycznych wykazała, że 110 przedsiębiorstw zadeklarowało wykorzystywanie rozwiązań big data w

\footnotetext{
${ }^{1}$ Do analizy wyników wykorzystano oprogramowanie STATISTICA Wersja 12.0.
} 
różnym zakresie przedmiotowym, co stanowi w przybliżeniu $41 \%$ obserwacji. Do dalszej analizy porównawczej wykorzystano wyłącznie odpowiedzi tych przedsiębiorstw. Wynika to $\mathrm{z}$ celu przyjętego w opracowaniu, którym jest wskazanie różnic $\mathrm{w}$ zakresie wykorzystania rozwiązań big data na tle różnorodnych cech charakterystycznych dla przedsiębiorstw.

W badaniu zidentyfikowano w pierwszej kolejności horyzont planowania strategicznego. Wyróżniono okres 1 roku, 2-3 lat, 5 lat, 10 lat i więcej. Wyniki empirycznej weryfikacji ukazują wykorzystanie rozwiązań big data ze względu na przyjętą różną perspektywę strategiczną (rysunek 3).

Spośród przedsiębiorstw uczestniczących w badaniu i wykorzystujących analizy big data najwięcej przyjmuje horyzont planowania strategicznego 5 lat oraz 10 lat i więcej. Jednocześnie uzyskane wyniki pozwalają stwierdzić relatywnie częstsze wykorzystywanie big data przez przedsiębiorstwa o długim horyzoncie czasowym.

Orientacje przedsiębiorstw w zarządzaniu zasadniczo się różnią. W literaturze wskazuję się między innymi orientację na klienta, orientację na innowacje, czy orientację na interesariuszy. W literaturze wymienia się jeszcze inne typy orientacji (np. orientacja zasobowa), ale na potrzebę badania wybrano wskazane wcześniej trzy z nich. Takie postępowanie umocowane było zakresem stosowania rozwiązań big data głównie dla celów marketingowych, społecznych i innowacyjnych przedsiębiorstwa. Oczekiwano, że u podmiotów wykazujących się dominującym zorientowaniem na klienta stosowanie analiz big data będzie częstsze ze względu na powszechną użyteczność tych rozwiązań wobec funkcji marketingowo-sprzedażowych, które bezpośrednio przyczyniają się do wzrostu przychodów. Wyniki przeprowadzonej analizy zaprezentowano na rysunku 4.

Rysunek 3. Stosowanie rozwiązań big data w przedsiębiorstwach o różnej perspektywie strategicznej $(\mathrm{N}=110)$

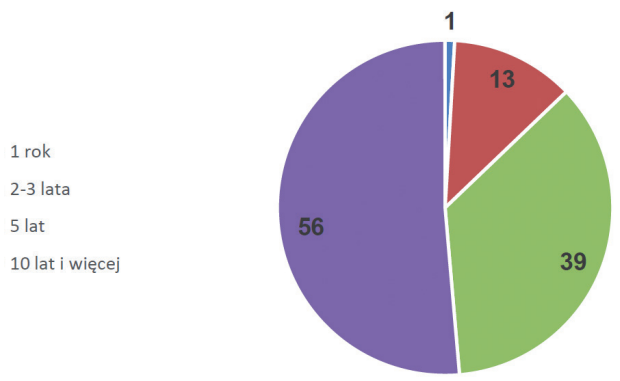

*wystąpił jeden brak odpowiedzi

Źródło: Opracowanie własne 
Wśród przedsiębiorstw deklarujących stosowanie big data w różnym zakresie przedmiotowym nie zidentyfikowano znaczących różnic dotyczących nastawienia do klienta, interesariuszy czy innowacji. Większość z nich legitymuje się zdecydowaną orientacją w każdym ze wskazanych kierunków (rysunek 4).

Badanie obejmowało również identyfikację ryzyka w relacjach z wybranymi przedsiębiorstwami. Menedżerowie ocenili w odniesieniu do których ze wskazanych interesariuszy występuje według nich największe możliwe ryzyko. Jednym z ważniejszych i często wymienianych obszarów zastosowania rozwiązań big data są analizy prowadzone pod kątem wykrywania ryzyka. Stąd zainteresowanie w analizie wykorzystywaniem big data w kontekście postrzegania ryzyka $\mathrm{w}$ relacjach $\mathrm{z}$ wybranymi interesariuszami przedsiębiorstwa. Wyniki przedstawiono na rysunku 5.

Analiza danych empirycznych dowiodła zasadniczego zróżnicowania postrzegania ryzyka w relacjach z interesariuszami przez przedsiębiorstwa, wśród których wykorzystuje się systemy analityczne big data. Wśród nich najwięcej wykazało, że relatywnie najczęściej dostrzega ryzyko w relacjach z konkurentami i klientami. Jednocześnie wyniki wskazują, że przedsiębiorstwa stosujące rozwiązania big data częściej dostrzegają ryzyko w relacjach z bliższymi interesariuszami.

Rysunek 4. Stosowanie rozwiązań big data w przedsiębiorstwach ze względu na dominujące orientacje $(\mathrm{N}=110)$

- orientacja na innowacje

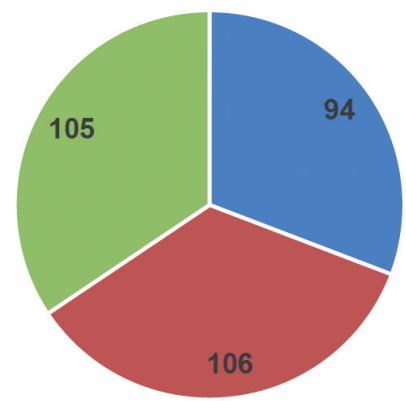

Źródło: Opracowanie własne

Rysunek 5. Stosowanie rozwiązań big data w przedsiębiorstwach ze względu na postrzeganie ryzyka w relacjach $\mathrm{z}$ interesariuszami $(\mathrm{N}=110)$ 


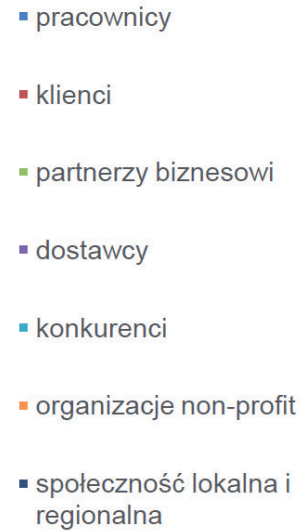

Źródło: Opracowanie własne

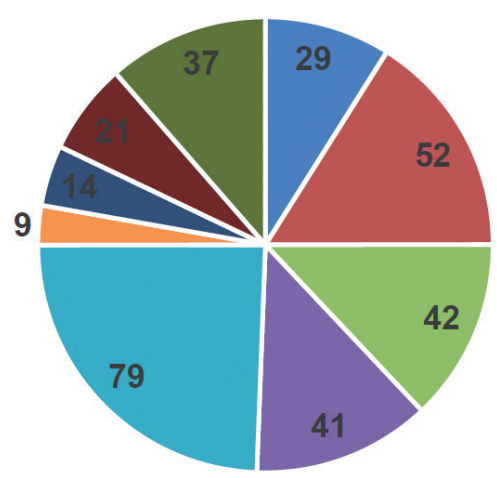

Przeprowadzona analiza zmiennych empirycznych wykazała różnice w stosowaniu analiz big data $\mathrm{w}$ kontekście horyzontu planowania strategicznego i ryzyka $\mathrm{w}$ relacjach $\mathrm{z}$ interesariuszami. $\mathrm{Z}$ kolei nie zidentyfikowano znaczących różnic $\mathrm{w}$ zakresie dominujących orientacji. $Z$ cała pewnością praktyczna użyteczność koncepcji big data w zarządzaniu przedsiębiorstwem jest widoczna, na co wskazuje zadeklarowane wykorzystywanie tego typu wspomaganie informacyjne u 110 podmiotów. Natomiast interesującym obszarem badawczy wydaje się być pogłębienie specyfiki dotyczącej analityki biznesowej w czasie rzeczywistym na tle kolejnych cech zarządzania przedsiębiorstwami. Pewnym jest, że koncepcja big data otwiera nowe możliwości i perspektywy rozwoju biznesu. Jak wiadomo dopasowanie na linii biznes - IT wymaga integracji na wielu płaszczyznach i w różnych obszarach przedsiębiorstwa zmieniając $\mathrm{w}$ ten sposób ich zachowania. Interesujące jest na ile systemy analityczne big data będą wpływać na konkurencyjność i rozwój przedsiębiorstw w przyszłości. Jak wskazuje Wielki [2014, s. 85] coraz częściej mówi się o nurcie związanym z powszechnym wśród firm konkurowaniem opartym o analityce (ang. competing on analytics).

\section{PODSUMOWANIE}

Wzrost zainteresowania koncepcją big data można dostrzec nie tylko wśród naukowców, ale także w firmach stosujących te rozwiązania w wielu obszarach biznesowych. Interesujące wydaje się na ile zmiana sposobu myślenia o analityce biznesowej nastawionej na analizę w czasie realnym przekłada się na zmia- 
nę zachowań przedsiębiorstw. Należy podkreślić, że choć rozwiązania big data mają ogromny potencjał to nie są jeszcze znane powszechnie ich możliwe konsekwencje wdrażania w przedsiębiorstwie.

W zaprezentowanych wynikach analizy zmiennych empirycznych przedstawiono wybrane z nich, które według autora stanowią ogólne zagadnienia poruszane w ramach problematyki zarządzania przedsiębiorstwem. Analiza obejmująca szerszy zakres zmiennych towarzyszy badaniom w większym projekcie.

\section{LITERATURA}

Elragal A., (2014), ERP and Big Data: The Inept Couple, Procedia Technology, Vol. 16.

Frizzo-Barker J., Chow-White P.A, Mozafari M., (2016), An empirical study of the rise of big data in business scholarship, "International Journal of Information Management", Vol. 36.

Gandomi A., Haider M., (2015), Beyond the hype: Big data concepts, methods, and analytics, International Journal of Information Management, Vol. 35.

Krauze S., (2014), Nowe spojrzenie na big data, Harvard Business Review, Nr 135.

Lau H.Y.K, Luo H., Zhong R.Y., Fang J., Huang G.Q., (2015), Special Issue on "Intelligent Enterprise Systems”, ,Computers \& Industrial Engineering, Vol. 84, No. 1-2.

Mach-Król M., (2015), Analiza i strategia big data w organizacjach, "Studies \& Proceedings of Polish Association for Knowledge Management", Vol. 41.

Mayer-Schönberger, Cukier K., (2014), Big Data, Rewolucja, która zmieni myślenie, pracę i życie, MT Biznes, Warszawa.

Özköse H., Ari E. S., Gencer C., (2015), Yesterday, Today and Tomorrow of Big Data, Social and Behavioral Sciences, Vol. 195.

Płoszajski P., (2013), Big Data: nowe źródło przewag i wzrostu firm, E-Mentor, Nr 3 (50).

Wamba S.F., Akter S., Edwards A., Chopin G., Gnanzou D., (2015), How 'big data'can make big impact: Findings from a systematic review and a longitudinal case study, International Journal Production Economics, Vol. 165.

Wienhofen L.W.M., Mathisen B.M., Roman D., (2015), Empirical Big Data: A Systematic Literature Mapping, Preprint submitted to Information Systems, September 11.

Wang Y., Kung L., Byrd T.A., (2016), Big data analytics: Understanding its capabilities and potential benefits for healthcare organizations, Technological Forecasting \& Social Change, (w druku).

Wielki J., (2014), Analiza możliwości wykorzystania zjawiska big data w e-biznesie, Systemy wspomagania organizacji, Prace Naukowe Uniwersytetu Ekonomicznego w Katowicach.

White M., (2012), Digital workplaces: vision and reality, "Business Information Review", Vol. 29, No. 4.

\section{THE USE OF BIG DATA SOLUTIONS IN BUSINESS MANAGEMENT}

Abstract: The article presents the concept of big data in enterprise management. The first part of paper concerns the nature and objectives of the big data approach. In the second part is introduced results of empirical research. Author use a comparative approach to indicated the differences in 
the exploit of big data solutions against various characteristics. The analysis helps to determine the specifics of the practical utility of the concept of big data in Polish enterprises.

Keywords: concept of big data, enterprise, management, support systems organization 